\title{
ADULT LEARNING AND SOCIALIZATION PROCESSES: RTA EXPERIENCE
}

\author{
Gatis Stafeckis \\ Rezekne Academy of Technologies, Latvia \\ Velta Lubkina \\ Rezekne Academy of Technologies, Latvia
}

\begin{abstract}
ERASMUS+ Strategic Partnership project Adult Self-Learning: Supporting Autonomy in a Technology-Mediated Environment/ ASL (Ref. No. 2019-1-TR01-KA204076875) co-funded by the Erasmus + programme, Key Action 2: Cooperation for innovation and the exchange of good practices - Strategic Partnerships for adult education. The project aims at teaching learners to acquire new skills and competences using learning innovative practices and digital technologies as well as developing a functioning collaborative learning environment to help them identify skills gaps and needs and to collaborate locally and independently for joint capacity-building. The ASL project is expected to produce three main results corresponding to three primary European priorities:

1. Supporting the setting up of, and access to, up skilling pathways (priority: adult lifelong learning);

2. Improving and extending the supply of high quality learning opportunities tailored to the needs of individual low-skilled or low-qualified adults (priority: social inclusion/further education opportunities);
\end{abstract}

3. Open education and innovative practices in a digital era (priority: adults' professionalization/empowerment).

Keywords: Adult lifelong learning, socialization processes, low skilled adults.

\section{Adult lifelong learning}

The aims of education policy in Latvia have been linked mainly with an economic development and the state identity for a long time. The compliance of education content to the requirements of labour market, education quality, as well as consolidation the state language in the education system have been the cornerstones of education policy during recent decades. (Golubeva, 2018)

Determining the trends of Latvia education policy in The Guidelines of Education Development for 2014 - 2020, priority trend of education policy has been emphasised: ensuring of special education needs in inclusive environment, incl. low skilled adults (https://likumi.lv/ta/id/303768).

In Latvia, adult education is officially defined as the "multi-dimensional educational process of persons (in age group 25-64) which ensures the development of the individual and his or her competitiveness in the labour 
market”. In line with the lifelong learning conception, adult education had incorporated three main concepts:

- Formal education - a system which includes levels of basic education, secondary education and higher education, and which assure professional qualification certificates, issued by the government.

- $\quad$ Non-formal education - any organized educational activities outside formal education system, such as courses, conferences, lectures, seminaries or workshops. The goal of non-formal education is to acquire new skills or improve knowledge and competences related to work, social and personal aims.

- Informal learning - is intentional, but less organized and also less structured, i.e., self-taught with the aim of improving the one own skills, consequently acquiring new knowledge. http://planipolis.iiep.unesco. org/upload/Latvia/Latvia_Education_Law.pdf

Taking into account the state of art of life-long learning in Europe, Latvia has implemented many activities to promote the development of adult education. The previous economic crisis has demonstrated the importance of an effective adult education strategy. (http://www.muzizglitiba.lv/izglitibas-politika). The support of the direct impact in the multifunctional participation of adults in lifelong learning is also the achievement indicator of the employment target because it limits the risk of structural unemployment. The Guidelines for the Development of Education 2014 - 2020 construct the strategic framework for the implementation and the development of adult education in Latvia

Implementing the action direction "Professionally-oriented adult and nonformal education” it is planned

- to develop strategies for lifelong learning and to ensure its launch at the regional level,

- $\quad$ the offer of second chance education for youth and adults and for adult education programs,

- to develop a methodology of evaluation and recognition for the informally acquired skills,

- $\quad$ planned activities for public awareness expansion to promote general understanding of value, skills and abilities of non-formal education, which it develops,

- $\quad$ to expand the offers of the universities in continuing education (in terms of regional development trends) and to develop a program to prepare teachers of adult education, to develop distance learning materials (university programs designed modules, which it can be mastered separately from the whole program),

- to expand the number of Internet access points for online/ distance learning. 
Lifelong learning is education of all your life long, which opens opportunities for everyone in society to improve their skills or acquire other qualifications according to the labor market demands, their interests and needs. Implementation of the lifelong learning principle contributes to the full value personal development and allow people to adapt better to the changes of a new era. Supporting the development of the lifelong learning principle, an outcome learning approach is emphasized which evaluates the acquired knowledge, skills and competence, rather than the way they have been obtained - in a formal, informal or non-formal learning way.

The term "adult education" is used to refer to both the process and the structures and institutions that are designed to promote adult education. According to the article 46 of the Law on Education adult education can be implemented in formal and informal education programs. The implementation of the formal adult education programs are determined by of the Education Law (http://likumi.lv/doc.php?id=50759); Vocational Training Act (http://likumi.lv/ doc.php?id=20244) and the Higher Education Law (http://likumi.lv/doc.php?id= 37967) standards.

In Latvia the current basic approach in adult education theory and practice includes:

- Action Learning, opportunities for mentoring and befriending are gradually offered in Latvia, learning through activities;

- $\quad$ Experiential Learning, emphasizing the action, event, events analysis and reflection, interpretation and generation of new knowledge;

- $\quad$ Project-based learning is based on different sources of information extraction which analyse and generate new knowledge;

- $\quad$ Self-directed Learning, which is characterized by the increased ability to monitor targets and identify personally meaningful evaluation criteria, regardless of the teacher, guidance, educational institutions, the stages or way of life;

- Intergenerational Learning;

- Interdisciplinarity, which includes access to education in different age groups, improvement of basic abilities and skills, to keep as long as possible person's a competitiveness on the labor market with the appropriate professional competence, risk groups, social inclusion, quality of lifelong education, including effectiveness, extension of providing lifelong learning programs (Koķe, 2012);

- A problem-based approach in adult education (Ali, 2019)

- $\quad$ Critical thinking (Chatfield, 2017, Rubene, 2012)

- Transformative digital learning (Mykhailenko \& all, 2019, Zogla, Prudnikova, \& Mykhailenko, 2019) 


\section{RTA experience in socialization processes}

The executor of the projects in the field of Personality Socialization is the Research institute of Regional Studies (REGI) of RTA (https://www.rta.lv/ en_regi) that implements the doctoral program "Pedagogy", (scientifis branchsocial pedagogy and special education) (https://www.rta.lv/regi doctoral_and_post_doctoral_research_aid) organizes the annual international conference "Society. Integration. Education" with articles available at Thomson Reuters WoS CI data base since 2007. (http://conferences.rta.lv/ index.php/SIE/SIE2018; https://www.rta.lv/regi_publicity (h-index in WOS- 4)

RTA holds appropriate experience in work with groups of social risk, low skilled people and projects creation for them and implementation of new technologies in the socialization processes (www.tdl.rta.lv; https://www.rta.lv/ regi_laboratories; etc.) REGI staff holds appropriate experience in the development of digital materials; since managing the State research program INOSOCTERHI new prototypes and e-modules have been implemented (http://www.telerehabilitation.lv), that are currently being introduced in education of Latvia.

REGI research in interdisciplinary fields:

- EDUCATION/ PERSONALITY SOCIALIZATION (5. Humanities and Social Sciences; 5.2. Social Sciences; 5.22. Pedagogy)

- $\quad$ RESOCIALIZATION/ (3. Biology and Medical Sciences; 3.15. Basic Medical Sciences - Public Health; Rehabilitation)

- INFORMATION TECHNOLOGIES (2. Engineering and Computer Sciences; 2.1 Computer Science; 2.11. Information Technologies).

In 2014-2019, the operation of 3 laboratories was activated, which serve as the research basis for the approbation of scientific studies:

- Laboratory of The Social Pedagogy and Rehabilitation Technologies provides an experimental basis for the approbation of REGI scientific studies, performs methodological work and provides social services for solutions to special and social education problems. In 2018, the laboratory was equipped with a Multisensory Room, https://www.youtube.com/watch?time_continue=82\&v=wted7CYWD $1 \mathrm{M}$ which is one of the most modern ones in the Baltic States, the equipment for which was purchased in the framework of INTERREG LAT-LIT projects MODPART LLI-223 (2012-2013) and POZCOPING LLI-163 (2017-2019) (https://www.rta.lv/citi_projekti? project_id=100) for research in social rehabilitation and stress reduction; In the framework of the State Research Programme INOSOCTEREHI (2014-2018) (www.telerehabilitation.lv), research was conducted for the introduction of telerehabilitation in inclusive 
education, and others, which ensure interdisciplinarity of research: Social Sciences (Education) -Medical Sciences (Rehabilitation) and Information Technologies.

Laboratory of Pedagogical Technologies

- provides an experimental basis for the approbation of REGI scientific studies, performs scientific and methodological work for the introduction of innovative technologies and the design of methodologies for solutions to education problems.

- In 2019, the laboratory was equipped with a modern video room in the framework of Fundamental and Applied Research Projects of the Latvian Council for Science during the project DocTDLL No lzp2018/2-0180 (2018-2020) for the introduction of transformative digital learning in Latvia on the basis of the approbation and adaptation of the models of the Canadian University of Ontario to the environment of Latvia (https://tdl.rta.lv/); Research into the introduction of digital social innovations in the scientific and cooperation programme project of Latvia and Ukraine "Gender Aspects of Digital Readiness and Human Capital Development in Regions” Project No LV-UA/2018/3 (2019-2020) (https://tdl.rta.lv/); and other EC projects. The Pedagogical Technology Laboratory (PTL) is the newest laboratory, and its operation has been activated by involving a foreign scientist (G.Marzano) who is currently very actively implementing interdisciplinary research in Social Work - Information Technologies.

Laboratory of Special Education

- $\quad$ The work of the Special Education Laboratory (SPL) primarily ensures the connection of science with society and practice, carrying out the design, approbation and introduction of preventive educational and correctional integrated programmes and methodologies in special education institutions in Latvia. 


\title{
Equipment of Laboratories
}

\author{
INTERREG LAT LIT project MODPART
}

The project research was carried out applying:

1. Vibromassage device;

2. Neuromuscular system testing device - Biodex 4 system;

3. Biosway system.
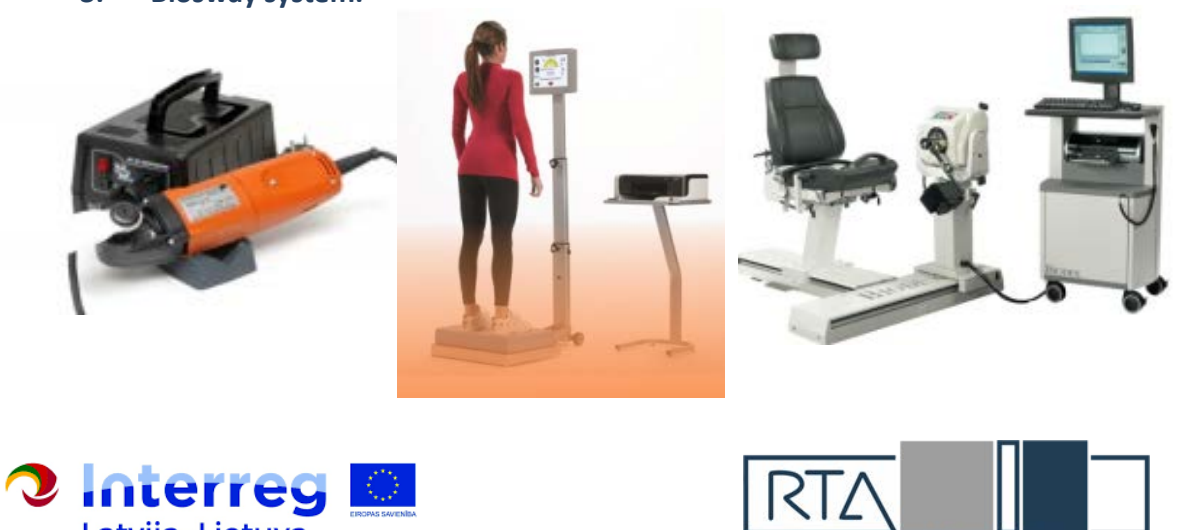

Latvija-Lietuva

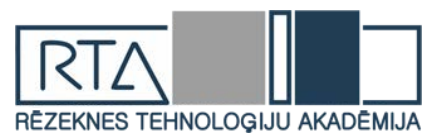

\section{Equipment of Laboratories}

\section{INTERREG LAT LIT project POZCOPING}

\begin{abstract}
Electroencephalography (EEG) data acquisition system

Electrical stimulation device

Alpha- Stim
\end{abstract}
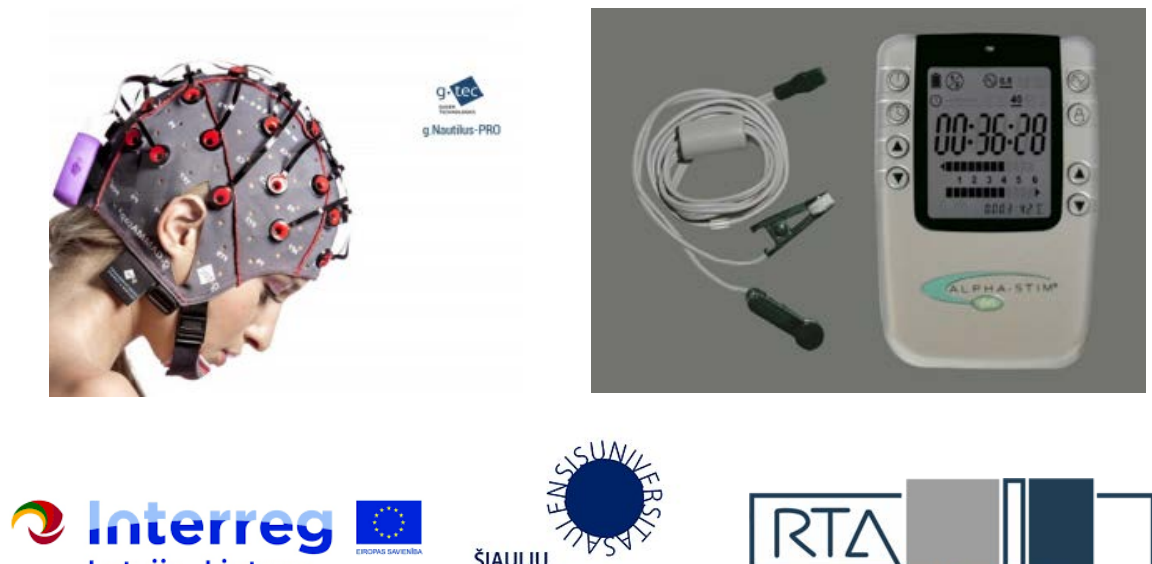

Latvija-Lietuva
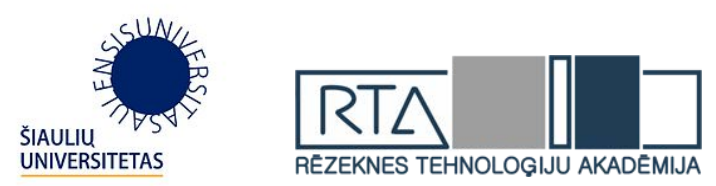

Figure 1 Examples and RTA equipment for socialization processes and stress management with people with disabilities, adolescents, low-qualified and low-skilled adults 


\section{SWOT analysis of RTA work with people with disabilities, adolescents, low- qualified and low-skilled adults}

\section{Strength}

- $\quad$ Academic work opportunities for people with disabilities, adolescents, low-qualified and low-skilled adults

- $\quad$ Scientific outcomes transfer in practice using modern laboratories with modern equipment

- $\quad$ Development of positive stress coping strategies using multisensory room;

- Implementation and development of methods, recognized by the leading researchers and applied in practice, providing support for successful socialization of people with disabilities, adolescents, lowqualified and low-skilled adults

\section{Weaknesses}

- We are scientific institute and there are lack of capacity / staff for the work with low skilled adults

\section{Opportunities}

- $\quad$ Projects development and financial support for activities with people with disabilities, adolescents, low-qualified and low-skilled adults

\section{Treats}

- $\quad$ Real situation regarding Corona virus in EU and Latvia

- $\quad$ Economical situation after Corona virus and decreasing EU finance for the projects development

\section{Acknowledgement}

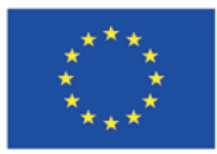

Co-funded by the

Erasmus+ Programme

of the European Union

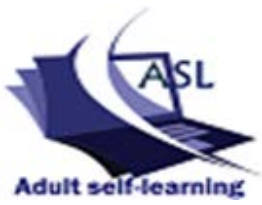

This article was supported by the EU Erasmus+ Strategic Partnership project “Adult Self-Learning: Supporting Learning Autonomy in a Technology-Mediated Environment Project Number: 2019-1-TR01-KA204-076875”

\section{References}

Ali, S.S. (2019). Problem Based Learning: A Student-Centered Approach. English Language Teaching 12(5), 73. DOI: 10.5539/elt.v12n5p73 /

Catfield, T. (2017). Critical Thinking. SAGE Publications Ltd.

Golubeva, M. (2018). Iekḷaušana - atbalsts - tasnīga izglītības sistēma. Retrieved from https://www.skola2030.lv/single-post/2018/05/21/Iek\%C4\%BCau\%C5\%A1ana- 
\%E2\%80\%93-atbalsts-\%E2\%80\%93-taisn\%C4\%ABga-izgl\%C4\%ABt\%C4\%ABbassist\%C4\%93ma

Koḳe, T. (2012). Mūžizglīīiba - autonoms ceḷojums kopīgā laikā un telpā. No V.Purēns (red.), Pieaugušo izglītība. Rakstu krājums Rīga: RaKa

LZA Terminoloǵijas komisija (2010). Par “Eiropas pieaugušo izglītības glosārija” terminiem. Retrieved from http://likumi.lv/doc.php?id=222079

LR Saeima (1995). Augstskolu likums. Retrieved from http://likumi.lv/doc.php?id=37967

LR Saeima (1998). Izglìtības likums. Retrieved from http://likumi.lv/doc.php?id=50759

LR Saeima (1999). Profesionālās izglìtības likums. Retrieved from http://likumi.lv/ doc.php?id=20244

Mykhailenko O., Blayone T., Žogla I., \& Luubkina V. (2019). Using Activity Theory for Modelling Transformative Digital Learning. 12. starptautiskās zinātniski praktiskās konferences "Vide. Tehnologija. Resursi" materiāli. DOI: http://dx.doi.org/ 10.17770/etr2019vol2.4044.

Ministru kabinets (2018). Noteikumi par valsts pamatizglìtības standartu un pamatizglìtības programmu paraugiem. Retrieved from https://likumi.lv/ta/id/303768.

Rubene, Z. (2012). Kritiskā domāšana pieaugušo izglīīīā. No V.Purēns (red.), Pieaugušo izglìtība. Rakstu krājums, 176-188.

Zogla, I., Prudņikova, I., \& Mykhailenko, O. (2019). Pedagogical assumptions of transformative digital model for Social Change, Society. Integration. Education. DOI: http://dx.doi.org/10.17770/sie2019vol1.3881. 
$* * *$

Iespiests SIA RA Drukātava

Kr.Valdemāra iela 8a, Rēzekne

www.radrukatava.lv 